\title{
Profiling Food Waste in the Hospitality Industry by Exploring Restaurant Managers' Attitudes
}

\author{
Mohamed Salah Ghanem \\ Higher Institute for Tourism, Hotels and Computer Sciences, El-Seyouf, Alexandria, Egypt.
}

\begin{abstract}
Most hospitality establishments are aiming at eliminating avoidable FW as a vital part of their cost control program. This action seems to be a standard and efficient tool in cutting operational costs. This research aims to track and identify the main reasons and sources of FW in the hospitality industry, identify top food categories related to FW and major FW causes in restaurants, determine the restaurant's opportunities to reduce the amount of wasted food and investigate restaurant managers' attitudes toward FW management concept, FW practices and guest's plate waste. Depending on the descriptive method, the research was accomplished through interviewing 47 restaurant's managers in Alexandria to determine the primary sources of restaurants' FW. The research questionnaire was developed to collect data from managers in restaurants that serves multi choices in their food menus and offers the opportunity to dine in. The reliability of the questionnaire was tested by calculating Cronbach's Alpha value (0.766). Statistical techniques of descriptive statistics were used. The research findings confirmed that there are positive attitudes toward FW management concepts, practices and profitable actions among restaurants' managers.
\end{abstract}

Keywords: Food Waste, Hospitality, Restaurant Attitudes, Practices.

\section{Introduction}

Food and Agriculture Organization reported that about one-third of the food produced for human consumption (over 1.3 billion tons) is wasted a year globally (Downing et al., 2015). Studies estimated that about half of all food grown is wasted before and after it reaches the consumer (Parfitt et al., 2010). The United States Environmental Protection Agency (2015) indicated that about $10 \%$ of purchased raw food is wasted before reaching plates. According to 2010 statistics, about 89 million tons of foods are discarded every year in Europe (European Commission, 2010). These enormous quantities of FW are estimated to be increased shortly as the prevention and control practices followed by food service organizations are not enough (Derqui et al., 2016). Such waste has severe negative economic, social, and environmental impacts (Kinasz et al., 2015). Most hospitality establishments are aiming at eliminating avoidable FW as a vital part of their cost control program. This action seems to be a standard and efficient tool in cutting operational costs (Marthinsen et al., 2012).

This research aims to:

- $\quad$ Track and identify the main reasons of FW in the hospitality industry.

- Identify top food categories related to FW and major FW causes in restaurants.

- Determine the restaurant's opportunities to reduce the amount of wasted food.

- Check restaurant managers' attitudes toward FW management concept, FW practices and plate waste.

\section{Literature review}

The Concept of $\mathrm{FW}$

Food and Agriculture Organization of the United Nations (2011) and the European Union Committee (2014) defined FW as "any edible part of food products related to human consumption that being discarded throughout the human food chain". In comparison to food loss, FW can be used to describe any waste that occurs when edible items go unconsumed because of 
human action or inaction (Bloom, 2011) often resulting in final consumption (Östergen and Gustavsson, 2014). It refers to any food that is of good quality and suitable for human consumption but does not get consumed and thrown away (Lipinski et al., 2013).

FW can be categorized into "avoidable" and "unavoidable" FW (Marthinsen, et al., 2012). Avoidable FW refers to all parts of foods that considered being edible by the vast majority of people but can no longer be consumed because of quality requirements, shelf life issues, hygiene rules or consumption habits (Papargyropoulou et al., 2014). It related to food thrown away while it is edible (e.g., slices of bread, apples, and meat) and could have been eaten if it had been better portioned, managed, stored and/or prepared (Hollins, 2013). Unavoidable FW refers to food parts that were never intended for human consumption and describes non-edible parts of food such as fruit skin, apple cores and meat bones (Falasconi et al., 2015). It related to waste arising from food preparation that is not and has not been edible under normal circumstances such as meat bones and eggshells (Hollins, 2013). The categorization of FW as avoidable and unavoidable varied according to many factors such as culture and religion (Betz et al., 2015).

\section{Causes of $F W$ in the Hospitality Industry}

Previous studies showed that about half of wastes resulted from the food and beverage sector are FWs (Kuhn, 2011; Manson, 2012); 65\% of these wastes occur during preparation, 30\% are resulted because of guests and 5\% are due to food spoilage. According to (Göbel et al., 2015) causes of FW can be summarized as the significant potential causes which are: quality standards, legal requirements, market conventions, human errors, technical issues, logistic issues and cultural influences.

In hospitality operations, waste should be expected to occur during any stage within the production process, from food acquisition to serving (Kitinoja, 2016). Several factors affect FW in hospitality establishments, namely inadequate meal planning, guests' food preferences and insufficient training of food workers (Ferreira et al., 2013). As causes of vegetables/fruit waste varied from the causes of fish and meat waste, it is clear that FW varies according to the characteristics and type of food served (Pirani and Arafat, 2015). The quantity of FW resulting from one food category varied from that resulting from another; across main courses served in restaurants and comparison to other main categories, fish items are generated higher wastes than poultry and meat items regarding plate waste. While fried items represented as the height percentage of waste, grilled items generated the lowest waste percentage (Ferreira et al., 2013). Compared to other meals, breakfast is less plate waste (Williams and Walton, 2011). Characteristics of food served such as shelf life, demand fluctuation and storage requirements have a significant impact on the level of waste (Mena et al., 2011). The type of restaurant can be also a factor; in quick service restaurants, the main causes of FW could be related to guest plate waste due to excessive portion sizes (Drewitt, 2013). FW volumes varied according to the day of meals as it can be increased during weekends and holidays and according to the mealtime as breakfast, lunch, and supper.

Demographic factors also affect the amount of FW left by the guest. Betz et al., (2015) found that women and younger guests were more likely to leave food when eating in restaurants.

Drewitt (2013) concluded the main causes of FW in the following:

- Lack of employees' training and awareness.

- Lack of management experience and support.

- Absence of FW measuring and monitoring.

- Absence of employees' incentives.

- Cooking too much food. 
- Insufficient maintenance of equipment.

- Excessive portion sizes.

- Consumption culture of guests and their lack of awareness.

- Promotional activities of restaurants that encourage guests to over order.

Recent studies indicated that portion sizes of food item served in food service establishments are between 2 to 8 times larger than standards set by USDA or FDA organizations, thus reflect in large amounts of wasted food in such establishments (Gunders, 2012). Beside served portion sizes, many other aspects affected the amount of FW. For example, dinnerware size on the selfserving buffet affects the amount of plate waste produced by guests (Wansink and van Ittersum, 2013). Plate waste in the hospitality industry refers to the quantity of edible served food that remains uneaten by guests (Ishdorj et al., 2015). It is measured by weighting uneaten food or by visual inspection of the amount of food remaining on the plate (Williams and Walton, 2011). Thus, the removable of trays in some events may result in lower plate waste (Kim and Morawski, 2012). In restaurants, it is observed that side dishes, because they are low-cost items, are often left by guests that makes vegetables and starch are top FW categories (Betz et al., 2015). Vegetables plate waste is higher than other items' plate waste. Plate waste in subsidized food service operations has always been higher than other operations related to the commercial sector. While estimated plate waste in restaurants and cafes are about $15 \%$, it can be up to $50 \%$ in hospitals due to patients' characteristics and cooking system (Williams and Walton, 2011).

According to Wright and Antonelli, (2015), there are some facts related to FW:

- $\quad 75 \%$ of FW is avoidable and could have been eaten .

- Carbohydrates, mainly potato, bread, pasta and rice, are the major food categories related to FW (about 40\%).

- When calculating the overall FW amounts, one meal is wasted from all 6 meals served around the world.

- According to FW causes, food preparation is the primary cause (45\%), followed by customer plates (34\%), then food spoilage (21\%).

\section{FW Management Concept and Practices}

According to Downing et al., (2015) $75 \%$ of total FW occurs in the hospitality industry is avoidable. By reducing FW, food service operations will save money, reduce environmental impacts, support community efforts and participate in hunger elimination (Schneider, 2013). It is logic to think about the FW not only as a cost price of wasted food, but also as the cost other resources invested throughout the food chain (Buzby and Hyman, 2012). According to the United States Environmental Protection Agency (2015), FWs cost the food service sector around \$100 billion annually. These costs are mainly distributed on wasted raw food costs, over-purchasing costs, labor costs and energy costs (Restaurant and Food Service Inspection in Canada, 2014). According to Marthinsen et al., (2012), the majority of wasted food, if managed, can be directed to people with needs and food banks to be an essential part of the hunger problem solution. Food Waste Reduction Alliance (2014) summarized the importance of FW management in the following:

- Economic: FW management is the most effective approach to save costs (labor cost to prepare, cook and serve wasted food and the cost of ingredients, energy, water, transportation and administration) in food service outlets.

- Social: Depending on data presented by the US Department of Agriculture, nearly 50 million Americans, including 16 million children, are food insecure as they haven't enough money to 
secure adequate nutrition. This number increased dramatically in developed country and make improving FW practices as a significant issue.

- Environmental: FW management programs are essential to save the environment, as preventing avoidable FW will reduce greenhouse gas emissions. There are many environmental resources (such as land, water, medications, chemicals, labor, and energy) used in food production. Many of these resources are non-renewable; therefore, cutting FW may contribute to save of these environmental resources.

According to Hollins (2013), FW management and practices are beginning with menu planning and continuous through demand forecasting, procurement of food, food storage and stock management, food preparation and portioning and serving. These practices are also extended to staff and guests' behaviors.

\section{The Role of Waste Monitoring in FW Management}

Hollins (2013) stated that the waste monitoring process helps food service establishments to identify waste generating areas. This process, according to Charlebois et al., (2015), must cover all the following areas:

- $\quad$ Spoilage FW: The FW resulting because of exceeding the expiration date.

- Preparation waste: Preventing inefficient preparation practices and cooking mistakes. It related to avoidable FW.

- Un-served edible food: It related to cooked food that thrown away as it wasn't ordered.

- Plate waste: knowing the reasons why guests didn't eat all of the served food. While some reasons might be related to portion size, others related to the quality of food.

As mentioned by Drewitt (2013), FW management practices should cover both:

- Pre-consumption waste: This type of waste can be defined as "FW generated by food production staff during preparation". The majority of such waste is happened in back areas (e.g., over-production, spoilage and over-cooked food).

- Post-consumption waste: This type of waste can be defined as "plate waste" that occurred by guests after the food serving.

\section{Portion Size Modification and FW Management}

For food service establishments, decreasing portion sizes can be useful in reducing the amount of FW (Food Wise Hong Kong, 2013). Freedman and Brochado, (2010) found a positive statistical significance between food portion size and plate waste. Studies referred that outside diners left about $17 \%$ of the ordered food at restaurants. The problem began in the U.S. since the 1970s as food outlets depend on larger portion sizes as a competitive advantage to attract consumers. This trend caused many healthy, social, environmental and economic problems. A considerable number of generated FWs is one of the most critical problems related to larger portion sizes (Lipinski et al., 2013). Reducing the portion size of served food (Freedman and Brochado, 2010) and changing plate size and shape (Kallbekken and Saelen, 2013) are among the most significant modifications that assist in FW reduction in both commercial and subsidized food service outlets. To decrease food waste, many school cafeterias and employee canteens implement "Offer Vs Serve" plan. According to such a plan, dinners should be offered all five required components (fruit, vegetable, grain, meat alternate, meat, and fluid milk) to choose 3 components of them to obtain later as a meal. Food providers in these establishments will only prepare food items selected by potential dinners. Thus, no unnecessary items are prepared. On the other hand, dinners will only select food items they preferred. Thus, no leftovers are generated (Williams and Walton, 2011). In Denmark, A la'carte menus are developed for hospitals to reduce patients' FW (Marthinsen, et al., 2012). 


\section{Behavior Modification concerning FW Management}

When dining out, attitudes and behavior of consumer play an essential role regarding the amount of wasted food (Lipinski et al., 2013). Depending on information presented by European Commission (2011), consumer's behavior modification is considered a critical factor in FW management. This factor is closed to cultural norms about dealing with food leftovers aiming to modify behaviors related to food production, distribution and consumption. Such a modification can be achieved through the suggested cycle appears in figure 2 .

Figure 1: Behavior Modification in Relation to FW Management.

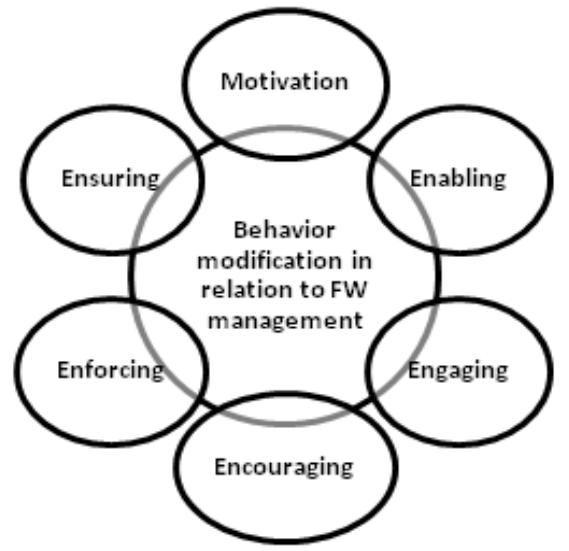

As shown in figure 1, the behavior modification program related to FW management can be divided into main 5 stages:

- Motivation: To gain support and loyalty, addressing FW management values, both economic and environmental, should be the starting point in behavior modification.

- Enabling: To make modification possible, sufficient information, training and expertise should be provided.

- Engaging: To discuss opportunities and threats, many and forums should be held on a community base. Such events should encourage experts and stakeholders to participate.

- Encouraging: To ensure modification, economic incentives, benchmarking and taxation should be provided as positive pressures.

- Enforcing: To enforce modification, many penalties should be implemented as negative pressure.

- Ensuring: To make the present modification a normal behavior in the near future, such a program should target young populations as food behaviors are often forming at early age.

\section{Staff and Guests' Responsibilities in FW Management}

According to a survey on food service sectors in Norway, Finland and Sweden, educating staff on waste reduction is the critical element in reducing avoidable FW (Marthinsen et al., 2012). Continual communication between management and staff in hospitality industry is represented as a vital solution for conveying goals and gaining feedback in regard to FW reduction (Gunders, 2012). Food service operation management should encourage staff to be friendly competitors in fields of FW reduction and control (Charlebois et al., 2015). WRAP, (2014) determined some responsibilities that should be taken by food service staff to reduce $\mathrm{FW}$ :

- Limit guest's order to only who can eat.

- Provide accurate and honest guidance on portion sizes.

- Encourage guests to choose their own portion size whenever possible.

- Ensure the attractiveness of presented meals. 
- Provide feed-back on unpopular menu items.

Islam (2016) indicated that societies should motivate their consumers to minimize FW depending on many ethical and religious motivators. Marthinsen et al., (2012) stated some factors for empowering guests to reduce their FW:

- Provide the best quality foods.

- Support menus with full information related to portion sizes, ingredients, cooking methods and nutritional and health considerations .

- Encourage guests to take their leftovers to eat them latter "Doggy Bag".

\section{FW Measurement methods}

According to UNEP, (2014), there are many methods that are followed in food service establishments to measure FW. These methods are aimed to quantify un-served meals by numbers, measure plate waste levels, investigate variation in waste levels across types and mealtimes and determine FW reasons to assist food service operators in action improvement. Depending on Marc et al., (2017), the most applicable FW measurement methods can be concluded in the followings:

- Visual check: While it is an effective and simple method, it can't be accurate and need vast experience to depend on.

- Measuring the financial loss: It is an effective and fully controllable method that works through calculating the cost of wasted food.

- Weighting FW: It is the most popular method used to calculate FW. However, this method could be used as a benchmarking tool, it related to many negative aspects. It may be impractical as FW must be weighted meal by meal and category by category. When used to measure FW in bulks, it doesn't identify what items have been wasted, thus future opportunities to reduce waste may be lost. It finally doesn't give the opportunity to isolate avoidable from unavoidable FW.

- Monitoring plate waste: For accurate FW controlling, there is a need to quantify served FW. It is recommended to be applied on a daily basis.

- Monitoring untouched meals: An untouched meal item needs special treatment. Reasons should be discussed with the guest.

\section{Research material and methods}

Depending on the descriptive method, the research was accomplished through interviewing of 47 restaurant's managers in Alexandria to determine the primary sources of restaurants' FW. The research questionnaire was developed to collect data from managers in restaurants that serve multi choices in their food menus and offers the opportunity to dine in. The reliability of questionnaire was tested by calculating Cronbach's Alpha value (0.766). Statistical techniques of descriptive statistics were used. The research questionnaire is composed of six sections as follows:

- The first section investigated managers' awareness of FW.

- The second section focused on profiling the restaurants' FW.

- The third one aimed to profile the menu items' FW.

- The fourth section investigated the restaurant managers' attitudes toward FW management concept.

- The fifth section investigated the restaurant managers' attitudes toward FW practices.

- The final section investigated the restaurant managers' attitudes toward guest's plate waste.

While the first three questionnaire sections using the style of multiplied choice questions, the other three questionnaire sections depending on five-point Likert-type scale with 1 indicated 
strongly disagree and 5 indicated strongly agree. The questionnaire, in general, tried to ask respondents about the main research questions which are:

- What are the main reasons for FW in hospitality industry?

- Which food categories can be considered as top FW resources?

- Which management practices can be positioned effectively to reduce FW in restaurants?

- Are there any opportunities in restaurants to reduce the amount of food wasted? If yes, what are these opportunities and how to exploit them?

These questions illustrated the problem of the research and reflected in composing the research hypotheses, which are:

- H1: There are positive attitudes toward FW management concept among restaurants' managers.

- H2: There are positive attitudes toward FW management practices among restaurants' managers.

- H3: There are positive attitudes toward profitable actions among restaurants' managers, even if they lead to more FW amounts.

\section{Results and discussions}

\section{Awareness toward FW among Research Sample}

Depending on data illustrated in the table (1), $83 \%$ of managers believe that their restaurants are aware of FW; however, only $36.2 \%$ of them decided that their restaurants know precisely how much food is lost.

Table1: Restaurants' Awareness toward FW.

\begin{tabular}{|c|c|c|c|c|c|}
\hline Sentences & Choices & $\begin{array}{l}F \\
47\end{array}$ & $\begin{array}{c}\% \\
100\end{array}$ & Mean & $\begin{array}{c}\text { Std. } \\
\text { Deviation }\end{array}$ \\
\hline \multirow[t]{2}{*}{ Our restaurant is aware of food waste. } & Yes & 39 & 83 & \multirow{2}{*}{1.17} & \multirow{2}{*}{0.380} \\
\hline & No & 8 & 17 & & \\
\hline \multirow{2}{*}{$\begin{array}{l}\text { Our restaurant knows exactly how much } \\
\text { food is lost. }\end{array}$} & Yes & 17 & 36.2 & \multirow{2}{*}{1.64} & \multirow{2}{*}{0.486} \\
\hline & No & 30 & 63.8 & & \\
\hline
\end{tabular}

\section{Restaurants' FW Profile}

In regard to profiling FW in restaurants as shown in table (2), about half of FW amount (51.1\%) occurs in front-areas and $40.4 \%$ occurs in back-areas. Thes results differ from what mentioned by Kuhn, (2011) and Manson, (2012) who indicated that most of the waste happened in back areas. The majority of FW related to back-areas occurs in the preparation areas $(51.1 \%)$ and kitchens $(31.9 \%)$. Regarding front-areas, the majority of waste is generated by female guests $(74.5 \%)$. Concerning age group, while children generate the majority of $\mathrm{FW}(72.3 \%)$, youth are the lowest FW generators (6.4\%). These outcomes confirm the findings of Betz et al., (2015), who found that women and younger guests were more likely to leave food when eating in restaurants.

The results also indicate that more than half of wasted food in restaurants' front areas is related to guests' plate waste (57.4\%). These results agreed with results of Williams and Walton, (2011), Gunders, (2012), Kim and Morawski, (2012), Wansink and van Ittersum, (2013) and Ishdorj et al., (2015).

Table 2: Restaurants' FW Profile.

\begin{tabular}{|c|c|c|c|c|c|}
\hline Sentences & Choices & $\begin{array}{c}F \\
47\end{array}$ & $\%$ & Mean & $\begin{array}{c}\text { Std. } \\
\text { Deviation }\end{array}$ \\
\hline \multirow{3}{*}{$\begin{array}{l}\text { The majority of food waste in our } \\
\text { restaurant occurs in: }\end{array}$} & Back Areas & 19 & 40.4 & \multirow[t]{3}{*}{1.68} & \multirow[t]{3}{*}{0.629} \\
\hline & Front Areas & 24 & 51.1 & & \\
\hline & I don't Know & 4 & 8.5 & & \\
\hline
\end{tabular}




\begin{tabular}{|c|c|c|c|c|c|}
\hline \multirow{5}{*}{$\begin{array}{l}\text { The majority of food waste occurs in back } \\
\text { areas is related to: }\end{array}$} & Storage areas & 4 & .5 & \multirow[t]{5}{*}{2.40} & \multirow[t]{5}{*}{0.771} \\
\hline & Preparation areas & 4 & 1.1 & & \\
\hline & Kitchens & 15 & 31.9 & & \\
\hline & $\begin{array}{l}\text { Others (Please } \\
\text { determine) }\end{array}$ & 4 & .5 & & \\
\hline & I don't Know & 0 & 0 & & \\
\hline \multirow{3}{*}{$\begin{array}{l}\text { The majority of food waste occurs in } \\
\text { front areas is related to: }\end{array}$} & Male guests & 8 & 17 & \multirow[t]{3}{*}{1.91} & \multirow[t]{3}{*}{0.503} \\
\hline & Female guests & 35 & 74.5 & & \\
\hline & I don't Know & 4 & 8.5 & & \\
\hline \multirow{4}{*}{$\begin{array}{l}\text { The majority of food waste occurs is } \\
\text { related to: }\end{array}$} & Elderly guests & 6 & 12.8 & \multirow[t]{4}{*}{2.77} & \multirow[t]{4}{*}{0.786} \\
\hline & Youth & 3 & 6.4 & & \\
\hline & Children & 34 & 72.3 & & \\
\hline & I don't Know & 4 & 8.5 & & \\
\hline \multirow{5}{*}{$\begin{array}{l}\text { The majority of wasted food in our } \\
\text { restaurant related to: }\end{array}$} & Raw foods & 4 & 8.5 & \multirow[t]{5}{*}{3.51} & \multirow[t]{5}{*}{1.040} \\
\hline & $\begin{array}{l}\text { Un-served prepared } \\
\text { foods }\end{array}$ & 3 & 6.4 & & \\
\hline & $\begin{array}{l}\text { Un-served cooked } \\
\text { foods }\end{array}$ & 9 & 19.1 & & \\
\hline & Plate wastes & 27 & 57.4 & & \\
\hline & I don't Know & 4 & 8.5 & & \\
\hline \multirow[t]{4}{*}{$\begin{array}{l}\text { The majority of wasted food in our } \\
\text { restaurant related to: }\end{array}$} & $\begin{array}{l}\text { Non edible (bones, } \\
\text { skins) }\end{array}$ & 33 & 70.2 & \multirow[t]{4}{*}{1.60} & \multirow[t]{4}{*}{1.012} \\
\hline & Expired by date & 4 & 8.5 & & \\
\hline & $\begin{array}{l}\text { Quality deviations } \\
\text { by production }\end{array}$ & 6 & 12.8 & & \\
\hline & I don't Know & 4 & 8.5 & & \\
\hline \multirow[t]{5}{*}{$\begin{array}{l}\text { The majority of wasted food in our } \\
\text { restaurant related to: }\end{array}$} & $\begin{array}{l}\text { Breakfast meal } \\
\text { period }\end{array}$ & 0 & 0 & \multirow[t]{5}{*}{3.17} & \multirow[t]{5}{*}{1.049} \\
\hline & Lunch meal period & 18 & 38.3 & & \\
\hline & Dinner meal period & 7 & 14.9 & & \\
\hline & $\begin{array}{l}\text { Unscheduled meal } \\
\text { periods }\end{array}$ & 18 & 38.3 & & \\
\hline & I don't Know & 4 & 8.5 & & \\
\hline
\end{tabular}

$70.2 \%$ of wasted food is categorized as non-edible parts such as bones and skins that differ from what confirmed by Antonelli, (2015). While the majority of FW amount resulted during both unscheduled meal periods and lunch meal periods $(38.3 \%)$, the lowest percentage of waste resulted at the dinner meal period (14.9\%). No participant chooses breakfast meal period as a waste generator period which confirmed the results of waste Williams and Walton, (2011) who indicated that compared to other meals, breakfast is less FW meal period.

\section{4-1- Menu Items' FW Profile}

As shown in table (3), profiling menu items in regard to FW indicates that the majority of FW is related to side orders (42.6\%) and salads (23.4\%). Main courses, bakery, beverages, desserts and sweets are the lowest items in relation to waste as no participant chooses any of them as a significant wasted food item. These results confirmed what indicated previously by Antonelli, (2015) and Betz et al., (2015) as they referred that side dishes are the most wasted items because of their low-cost. 
Table 3: Menu Items' FW Profile.

\begin{tabular}{|c|c|c|c|c|c|}
\hline Sentences & Choices & $\begin{array}{c}\mathbf{F} \\
(47) \\
\end{array}$ & $\%$ & Mean & Std. Deviation \\
\hline \multirow{10}{*}{$\begin{array}{l}\text { 1. The majority of wasted food in } \\
\text { our restaurant related to: }\end{array}$} & Appetizers & 6 & 12.8 & \multirow[t]{10}{*}{4.40} & \multirow[t]{10}{*}{2.593} \\
\hline & soups & 4 & 8.5 & & \\
\hline & Salads & 11 & 23.4 & & \\
\hline & Main courses & 0 & 0 & & \\
\hline & Side orders & 20 & 42.6 & & \\
\hline & Bakery & 0 & 0 & & \\
\hline & Desserts and sweets & 0 & 0 & & \\
\hline & Beverages & 0 & 0 & & \\
\hline & Others (please determine) & 0 & 0 & & \\
\hline & I don't Know & 6 & 12.8 & & \\
\hline \multirow{7}{*}{$\begin{array}{l}\text { The majority of wasted food in } \\
\text { our restaurant related to: }\end{array}$} & Baked food & 5 & 10.6 & \multirow[t]{7}{*}{4.11} & \multirow[t]{7}{*}{1.564} \\
\hline & Grilled food & 1 & 2.1 & & \\
\hline & Boiled food & 9 & 19.1 & & \\
\hline & Stewed food & 9 & 19.1 & & \\
\hline & Fried food & 19 & 40.4 & & \\
\hline & Others (please determine) & 0 & 0 & & \\
\hline & I don't Know & 4 & 8.5 & & \\
\hline \multirow{3}{*}{$\begin{array}{l}\text { The majority of wasted food in } \\
\text { our restaurant related to: }\end{array}$} & Dry food & 8 & 17 & \multirow{3}{*}{2.04} & \multirow{3}{*}{0.624} \\
\hline & Sauced food & 29 & 61.7 & & \\
\hline & I don't Know & 10 & 21.3 & & \\
\hline \multirow{5}{*}{$\begin{array}{l}\text { Concerning the main courses, the } \\
\text { top food waste item in our } \\
\text { restaurant is: }\end{array}$} & Meat items & 5 & 10.6 & \multirow{5}{*}{3.13} & \multirow{5}{*}{1.279} \\
\hline & Poultry items & 8 & 17.0 & & \\
\hline & Fish items & 22 & 46.8 & & \\
\hline & Others (please determine) & 0 & 0 & & \\
\hline & I don't Know & 12 & 25.5 & & \\
\hline \multirow{8}{*}{$\begin{array}{l}\text { In relation to side orders, the top } \\
\text { food waste item in our restaurant } \\
\text { is: }\end{array}$} & Soups & 4 & 8.5 & \multirow{8}{*}{4.19} & \multirow{8}{*}{2.071} \\
\hline & Salads & 6 & 12.8 & & \\
\hline & Vegetables & 8 & 17.0 & & \\
\hline & Macaroni & 12 & 25.5 & & \\
\hline & Rice & 7 & 14.9 & & \\
\hline & Potatoes & 3 & 6.4 & & \\
\hline & Others (please determine) & 0 & 0 & & \\
\hline & I don't Know & 7 & 14.9 & & \\
\hline \multirow{3}{*}{$\begin{array}{l}\text { Concerning the desserts, the } \\
\text { majority of wasted items in our } \\
\text { restaurant related to: }\end{array}$} & Soft textures desserts & 29 & 61.7 & \multirow{3}{*}{1.62} & \multirow{3}{*}{0.848} \\
\hline & Hard textures desserts & 7 & 14.9 & & \\
\hline & I don't Know & 11 & 23.4 & & \\
\hline \multirow{6}{*}{$\begin{array}{l}\text { In relation to beverages, the top } \\
\text { beverage waste item in our } \\
\text { restaurant is: }\end{array}$} & Hot beverages & 6 & 12.8 & \multirow[t]{6}{*}{3.62} & \multirow[t]{6}{*}{1.468} \\
\hline & Soft drinks & 5 & 10.6 & & \\
\hline & Cocktails & 4 & 8.5 & & \\
\hline & Mineral water & 25 & 53.2 & & \\
\hline & Others (please determine) & 0 & 0 & & \\
\hline & I don't Know & 7 & 14.9 & & \\
\hline
\end{tabular}

Investigating $\mathrm{FW}$ in relation to cooking methods shows that fried food items are the top wasted items $(40.4 \%)$, followed by both stewed and boiled food items (19.1\%) and soups (8.5\%). The majority of waste is related to sauce food (61.7\%) compared to dry food (17\%). Scanning of 
main courses to determine top FW items refereed that fish items are the top (46.8\%) followed by poultry items $(17 \%)$. Meat items are at the end of the list (10.6\%). These results confirmed the outcomes of Pirani and Arafat, (2015) in confirming that there is a relationship between the type of food served and the amount of waste. These also are matched with Ferreira et al., (2013) who emphasized that fish is the major wasted item.

In relation to side orders, macaroni is the top waste item (25.5\%) followed by vegetables (17\%), rice $(14.9 \%)$, salads $(12.8 \%)$, soups $(8.5 \%)$ and potatoes $(6.4 \%)$ that matched with what referred by Antonelli, (2015) who confirmed that carbohydrates are the primary food categories related to FW. Soft textures desserts $(61.7 \%)$ are excel over hard textures desserts $(14.9 \%)$ in regarding of waste rates. Ranking beverage according to waste rates indicates that mineral water is the top (53.2\%) followed by hot beverages (12.8\%), soft drinks (10.6\%) and cocktails (8.5\%).

\section{Managers Attitudes toward FW Management Concept}

As shown in table (4), while $93.6 \%$ of managers indicated that zero controllable FW is an impossible target, $95.8 \%$ of them emphasized that reducing FW may be a challenging process. However, as it provides valuable positive results, more attention and efforts should be directed to it. $83 \%$ of managers indicated that measuring wastes in all food handling and processing stages become a major for adapting FW management systems. Therefore, many modifications should be made in fields of food handling to reduce FW generation (87.1\%) and special care about all FWs should be considered with particular attention to post customer wastes (68\%). While $46.9 \%$ of managers believed that food service establishments should agree to any practice that helps to raise $\mathrm{FW}$ awareness among consumers and employees, $46.8 \%$ of them refuse this practice as it might leads to a profit margin reduction.

Table 4: Managers Attitudes toward FW Management Concept

\begin{tabular}{|c|c|c|c|c|c|c|c|c|c|c|}
\hline \multirow[t]{2}{*}{$\begin{array}{l}\text { Attitudes toward FW Management } \\
\text { Concept }\end{array}$} & \multicolumn{5}{|c|}{ Choice } & \multicolumn{3}{|c|}{$\begin{array}{ll}\text { Central } & \text { Tendency } \\
\text { Measures } & \\
\end{array}$} & \multicolumn{2}{|l|}{$\begin{array}{l}\text { Dispersion } \\
\text { Measures }\end{array}$} \\
\hline & SA & $\mathbf{A}$ & $\mathbf{N}$ & D & SD & Mean & Median & Mode & $\begin{array}{l}\text { Std. } \\
\text { Deviation }\end{array}$ & Range \\
\hline $\begin{array}{l}\text { Zero controllable food waste is an } \\
\text { impossible target. }\end{array}$ & $\begin{array}{l}40 \\
85.1\end{array}$ & $\begin{array}{l}4 \\
8.5\end{array}$ & $\begin{array}{l}3 \\
6.4\end{array}$ & $\begin{array}{l}0 \\
0\end{array}$ & $\begin{array}{l}0 \\
0\end{array}$ & 4.79 & 5 & 5 & 0.549 & 2 \\
\hline $\begin{array}{l}\text { Reducing food waste may be a } \\
\text { challenging process, but as it provides } \\
\text { valuable positive results, more attention } \\
\text { and efforts should be directed to it. }\end{array}$ & $\begin{array}{l}28 \\
59.6\end{array}$ & $\begin{array}{l}17 \\
36.2\end{array}$ & $\begin{array}{l}2 \\
4.3\end{array}$ & $\begin{array}{l}0 \\
0\end{array}$ & $\begin{array}{l}0 \\
0\end{array}$ & 4.55 & 5 & 5 & 0.583 & 2 \\
\hline $\begin{array}{l}\text { Measuring wastes in all food handling } \\
\text { and processing stages become a major } \\
\text { for adapting food waste management } \\
\text { systems. }\end{array}$ & $\begin{array}{l}28 \\
59.6\end{array}$ & $\begin{array}{l}11 \\
23.4\end{array}$ & $\begin{array}{l}8 \\
17\end{array}$ & $\begin{array}{l}0 \\
0\end{array}$ & $\begin{array}{l}0 \\
0\end{array}$ & 4.43 & 5 & 5 & 0.773 & \\
\hline $\begin{array}{l}\text { Many modifications should be made in } \\
\text { the fields of food handling to reduce } \\
\text { food waste generation. }\end{array}$ & $\begin{array}{l}12 \\
25.5\end{array}$ & $\begin{array}{l}29 \\
61.7\end{array}$ & $\begin{array}{l}5 \\
10.6\end{array}$ & $\begin{array}{l}1 \\
2.1\end{array}$ & $\begin{array}{l}0 \\
0\end{array}$ & 4.11 & 4 & 4 & 0.667 & \\
\hline $\begin{array}{l}\text { While special care about all food wastes } \\
\text { should be considered, the majority of } \\
\text { attention should be given to post } \\
\text { customer wastes. }\end{array}$ & $\begin{array}{ll}5 \\
10.6\end{array}$ & $\begin{array}{l}27 \\
57.4\end{array}$ & $\begin{array}{l}8 \\
17\end{array}$ & $\begin{array}{l}7 \\
14.9\end{array}$ & $\begin{array}{l}0 \\
0\end{array}$ & 3.64 & 4 & 4 & 0.870 & \\
\hline $\begin{array}{l}\text { Ethically, food service establishments } \\
\text { should agree to any practice that helps to } \\
\text { raise food waste awareness among } \\
\text { consumers and employees, even if it } \\
\text { leads to a profit margin reduction. }\end{array}$ & $\begin{array}{l}2 \\
4.3\end{array}$ & $\begin{array}{l}20 \\
42.6\end{array}$ & $\begin{array}{l}3 \\
6.4\end{array}$ & $\begin{array}{l}22 \\
46.8\end{array}$ & $\begin{array}{l}0 \\
0\end{array}$ & 3.04 & 3 & 2 & 1.042 & 3 \\
\hline
\end{tabular}




\section{Restaurants' Managers Attitudes toward FW Practices}

Depending on the data of table (5), managers are agreed with many practices that contribute in FW reduction. They referred that replacing fresh ingredients with canned and frozen ingredients $(61.7 \%)$, reusing unused bread in breading of fried items $(85.1 \%)$, offering a half portion size and offering the other half when ordered $(66 \%)$, availability of children's menus with smaller portions $(89.3 \%)$ and serving of side dishes as an optional (68.1\%) might help in FW reduction.

Table 5: Managers Attitudes toward FW Practices

\begin{tabular}{|c|c|c|c|c|c|c|c|c|c|c|}
\hline \multirow[t]{2}{*}{$\begin{array}{lll}\text { Attitudes } & \text { toward } & \text { FW } \\
\text { Practices } & & \end{array}$} & \multicolumn{5}{|c|}{ Choice } & \multicolumn{3}{|c|}{$\begin{array}{l}\text { Central } \\
\text { Measures }\end{array}$} & \multicolumn{2}{|l|}{$\begin{array}{l}\text { Dispersion } \\
\text { Measures }\end{array}$} \\
\hline & SA & Ae & $\mathbf{N}$ & D & SD & Mean & Median & Mode & $\begin{array}{l}\text { Std. } \\
\text { Deviation }\end{array}$ & Range \\
\hline $\begin{array}{l}\text { Replacing Fresh ingredients } \\
\text { with canned and frozen } \\
\text { ingredients supports food waste } \\
\text { reduction. }\end{array}$ & $\begin{array}{l}24 \\
51.1\end{array}$ & $\begin{array}{l}5 \\
10.6\end{array}$ & $\begin{array}{l}12 \\
25.52\end{array}$ & $\begin{array}{l}6 \\
12.8\end{array}$ & $\begin{array}{l}0 \\
0\end{array}$ & 4 & 5 & 5 & 1.142 & 3 \\
\hline $\begin{array}{l}\text { Reusing unused bread in } \\
\text { breading of fried items may be } \\
\text { useful in waste reduction. }\end{array}$ & $\begin{array}{l}23 \\
48.9\end{array}$ & $\begin{array}{l}17 \\
36.2\end{array}$ & $\begin{array}{l}2 \\
4.3\end{array}$ & $\begin{array}{l}2 \\
4.3\end{array}$ & $\begin{array}{l}3 \\
6.4\end{array}$ & 4.17 & 4 & 5 & 1.129 & 4 \\
\hline $\begin{array}{l}\text { Offering a half portion size and } \\
\text { offering the other half when } \\
\text { ordered may be an effective } \\
\text { practice in food waste } \\
\text { reduction. }\end{array}$ & $\begin{array}{l}18 \\
38.3\end{array}$ & $\begin{array}{l}13 \\
27.7\end{array}$ & $\begin{array}{l}11 \\
23.4\end{array}$ & $\begin{array}{l}4 \\
8.5\end{array}$ & $\begin{array}{l}1 \\
2.1\end{array}$ & 3.91 & 4 & 5 & 1.080 & 4 \\
\hline $\begin{array}{l}\text { Availability of children's } \\
\text { menus with smaller portions } \\
\text { may be useful practice in food } \\
\text { waste management. }\end{array}$ & $\begin{array}{l}5 \\
31.9\end{array}$ & $\begin{array}{l}7 \\
7.4\end{array}$ & $\begin{array}{l}5 \\
10.6\end{array}$ & 0 & 0 & 4.21 & 4 & 4 & 0.623 & 2 \\
\hline $\begin{array}{l}\text { Serving of side dishes as an } \\
\text { optional may help in food } \\
\text { waste reduction. }\end{array}$ & $\begin{array}{l}13 \\
27.7\end{array}$ & $\begin{array}{l}19 \\
40.4\end{array}$ & $\begin{array}{l}11 \\
23.4\end{array}$ & $\begin{array}{l}3 \\
6.4\end{array}$ & $\begin{array}{l}1 \\
2.1\end{array}$ & 3.85 & 4 & 4 & 0.978 & 4 \\
\hline
\end{tabular}

\section{4-2- Restaurants' Managers Attitudes toward Guest's Plate Waste}

As shown in table (6), while $61.1 \%$ of managers refusing that managing plate wastes is an impossible action and $81.1 \%$ refusing to neglect measuring what guests leave on their plates, only $48.9 \%$ believed that raising guests' awareness toward FW management doesn't lead to profit reduction (48.9\%). They agreed to encourage guests to take their leftover away $(78.7 \%)$, but they refused to change their serving sizes to be smaller as they believed that guests prefer to dine in restaurants that serve more sizes and quantities (61.7\%). They found no maters to encourage food servers to motivate guests to order more quantities and items to achieve sales targets even if it generates more wastes (74.4\%). These results are matched with Drewitt (2013) who referred that the main causes of FW are the absence of measuring and monitoring, excessive portion sizes and promotional activities of restaurants that encourage guests to over order.

Table 6: Managers Attitudes toward Guest's Plate Waste.

\begin{tabular}{|c|c|c|c|c|c|c|c|c|c|c|}
\hline \multirow[t]{2}{*}{$\begin{array}{l}\text { Attitudes toward Guest's Plate } \\
\text { Waste }\end{array}$} & \multicolumn{5}{|c|}{ Choice } & \multicolumn{3}{|c|}{$\begin{array}{l}\text { Central Tendency } \\
\text { Measures }\end{array}$} & \multicolumn{2}{|c|}{$\begin{array}{l}\text { Dispersion } \\
\text { Measures }\end{array}$} \\
\hline & SA & $\mathbf{A}$ & $\mathbf{N}$ & D & SD & Mean & Median & Mode & $\begin{array}{l}\text { Std. } \\
\text { Deviation }\end{array}$ & Range \\
\hline $\begin{array}{l}\text { 1. Managing plate wastes is an } \\
\text { impossible action, as the majority } \\
\text { of plate wastes are the guests' } \\
\text { responsibility. }\end{array}$ & $\begin{array}{l}0 \\
0\end{array}$ & $\begin{array}{l}6 \\
12.8\end{array}$ & $\begin{array}{l}12 \\
25.5\end{array}$ & $\begin{array}{l}5 \\
10.6\end{array}$ & $\begin{array}{l}24 \\
51.1\end{array}$ & 2 & 1 & 1 & 1.142 & 3 \\
\hline 2. Measuring what guests leave on & 3 & 2 & 2 & 18 & 22 & 1.85 & 2 & 1 & 1.122 & 4 \\
\hline
\end{tabular}




\begin{tabular}{|c|c|c|c|c|c|c|c|c|c|c|}
\hline \multirow[t]{2}{*}{$\begin{array}{l}\text { Attitudes toward Guest's Plate } \\
\text { Waste }\end{array}$} & \multicolumn{5}{|c|}{ Choice } & \multicolumn{3}{|c|}{$\begin{array}{l}\text { Central Tendency } \\
\text { Measures }\end{array}$} & \multicolumn{2}{|l|}{$\begin{array}{l}\text { Dispersion } \\
\text { Measures }\end{array}$} \\
\hline & SA & $\mathbf{A}$ & $\mathbf{N}$ & D & SD & Mean & Median & Mode & $\begin{array}{l}\text { Std. } \\
\text { Deviation }\end{array}$ & Range \\
\hline $\begin{array}{l}\text { their plates isn't a very important } \\
\text { process as costs of such a waste } \\
\text { loaded to guests. }\end{array}$ & 6.4 & 4.3 & 4.3 & 38.3 & 46.8 & & & & & \\
\hline $\begin{array}{l}\text { 3. Raising guests' awareness toward } \\
\text { food waste management leads to } \\
\text { profit reduction. }\end{array}$ & $\begin{array}{l}4 \\
8.5\end{array}$ & $\begin{array}{l}8 \\
17\end{array}$ & $\begin{array}{l}12 \\
25.5\end{array}$ & $\begin{array}{l}12 \\
25.5\end{array}$ & $\begin{array}{l}11 \\
23.4\end{array}$ & 2.62 & 3 & 2 & 1.261 & 4 \\
\hline $\begin{array}{l}\text { 4. Encouraging guests to take their } \\
\text { leftover away may annoy them. }\end{array}$ & $\begin{array}{l}0 \\
0\end{array}$ & $\begin{array}{ll}5 \\
10.6\end{array}$ & $\begin{array}{l}5 \\
10.6 \\
\end{array}$ & $\begin{array}{l}23 \\
48.9 \\
\end{array}$ & $\begin{array}{ll}14 \\
29.8 \\
\end{array}$ & 2.02 & 2 & 2 & 0.921 & 3 \\
\hline $\begin{array}{l}\text { 5. Guests prefer to dine in } \\
\text { restaurants that serve more sizes } \\
\text { and quantities, so our restaurant } \\
\text { can't change their serving sizes to } \\
\text { be smaller. }\end{array}$ & $\begin{array}{l}8 \\
17\end{array}$ & $\begin{array}{l}21 \\
44.7\end{array}$ & $\begin{array}{l}11 \\
23.4\end{array}$ & $\begin{array}{l}4 \\
8.5\end{array}$ & $\begin{array}{l}3 \\
6.4\end{array}$ & 3.57 & 4 & 4 & 1.078 & 4 \\
\hline $\begin{array}{l}\text { 6. Food Servers should motivate } \\
\text { guests to order more quantities and } \\
\text { items to achieve sales even if it } \\
\text { generates more wastes. }\end{array}$ & $\begin{array}{l}30 \\
63.8\end{array}$ & $\begin{array}{l}5 \\
10.6\end{array}$ & $\begin{array}{l}1 \\
2.1\end{array}$ & $\begin{array}{l}11 \\
23.4\end{array}$ & $\begin{array}{l}0 \\
0\end{array}$ & 4.15 & 5 & 5 & 1.268 & 3 \\
\hline
\end{tabular}

\section{Data Analysis}

Data analysis is summarized in the test of research hypotheses that could be illustrated in the following points:

- H1: There are positive attitudes toward FW management concept among restaurants' managers: By using Paired Samples T-Test, the results showed that there is a statistically significant (pvalue $=0.000)$ positive $(\mathrm{T}=29.753)$ relation between managers' awareness of $\mathrm{FW}$ and their attitudes toward FW management concept (See table 7). According to such positive significant relationship, the research accepts the $1^{\text {st }}$ hypothesis.

- H2: There are positive attitudes toward FW management practices among restaurants' managers: Depending on the results of Paired Samples T-Test, the results showed that there is a statistically significant $(\mathrm{p}$-value $=0.000)$ positive $(\mathrm{T}=27.471)$ relation between managers' awareness of FW and their attitudes toward FW management practices (review table 8). According to such positive significant relationship, the research accepts the $2^{\text {nd }}$ hypothesis.

- H3: There are positive attitudes toward profitable actions among restaurants' managers even if they lead to more FW amounts: By using Paired Samples T-Test, the results showed that there is a statistically significant ( $\mathrm{p}$-value $=0.000)$ positive $(\mathrm{T}=23.477)$ relation between managers' awareness of FW and their attitudes toward profitable actions even if they lead to more FW amounts (See table 8). According to such positive significant relationship, the research accepts the $3^{\text {rd }}$ hypothesis.

Table 7: Paired Samples T-Test.

\begin{tabular}{|c|l|c|c|c|}
\hline \multicolumn{1}{|c|}{ Hypotheses } & T & Sig. & Result \\
\hline 1 & $\begin{array}{l}\text { There are positive attitudes toward FW management concept } \\
\text { among restaurants' managers }\end{array}$ & 29.753 & 0.000 & Supported \\
\hline 2 & $\begin{array}{l}\text { There are positive attitudes toward FW management practices } \\
\text { among restaurants' managers }\end{array}$ & 27.471 & 0.000 & Supported \\
\hline 3 & $\begin{array}{l}\text { There are positive attitudes toward profitable actions among } \\
\text { restaurants' managers even if they lead to more FW amounts. }\end{array}$ & 23.477 & 0.000 & Supported \\
\hline
\end{tabular}




\section{Conclusions and recommendations}

Research results showed that there is a positive statistically significant relationship between managers' awareness of FW and their attitudes toward FW management concept, FW management practices and profitable actions even if they lead to more FW amounts. The research's results have some limitations. Firstly, these results are related to only 47 restaurants in Alexandria; therefore, the descriptive and analytical results couldn't be generalized to all restaurants and food service outlets neither in Alexandria nor in Egypt. It means that these results can be used only as indicators for food and beverage establishments. Secondly, the research concentrated on only one type of food service operations that serves multi choices in their food menus and offer the opportunity to dine in (restaurants). Thus, excluding other types of food service outlets make it difficult to generalize results to cover all types of food service establishments. Finally, all research's data related to restaurants' managers perspective and no data is related to guests nor employees point of views. Depending on that, the research recommended other researchers to focus on greater sample size in various types of food service operations from different Egyptian cities with concentrating on managers, employees and guests point of views in the way that allow generalizing results.

\section{References}

Betz, A., Buchli, J.J., Göbel, C., Müller, C., Göbel, C., \& Müller, C. (2015). Food waste in the Swiss food service industry: Magnitude and potential for reduction. Waste Management, 35: 218-226.

Bloom, J. (2011). American Wasteland: How America throws away Nearly Half of Its Food and What We Can Do about It. Da Capo Press: Cambridge, MA, USA.

Buzby, J.C., \& Hyman, J. (2012). Total and per capita value of food loss in the United States. Food Policy, 37(5), 561-570.

Charlebois, S., Creedy, A., \& von Massow, M. (2015). Back of house- focused study on food waste in fine dining: The case of Delish restaurants. International Journal of Culture Tourism and Hospitality Research, 9(3), 278-291.

Derqui, B., Fayos, T., \& Fernandez, V. (2016). Towards a More Sustainable Food Supply Chain: Opening up Invisible Waste in Food Service. Sustainability, 8, 1-20.

Downing, E., Priestley, S., \& Carr, W. (2015). Food Waste, Briefing Paper Number CBP07045, 2 September. Last Online retrieved at December, 25 from: (http://www.organicsrecycling.org.uk/uploads/article3082/HoC\%20Research\%20Paper\%20Food\%20Waste\%20\%20Sept\%202015.pdf).

Drewitt, T. (2013). Food waste prevention in quick service restaurants: A comparative case study on the quantity, source, cost and cause. Master Thesis of Science in Environmental Management and Policy, Lund, Sweden, September. Last Online retrieved at December, 25 from: (http://lup.lub.lu.se/luur/download?func=downloadFile\&recordOId=4080877\&fileOId=4080 $\underline{878}$.

European Commission, (2010). Preparatory study on food waste across EU 27. Brussels, Belgium: Luxembourg. Last Online retrieved at December, 25 from: (http://ec.europa.eu/environment/eussd/pdf/bio_foodwaste_report.pdf).

European Commission. (2011). Guidelines on the Preparation of Food Waste Prevention Programs. [Online] Available: United States Environmental Protection Agency, (2015). Reducing Wasted Food \& Packaging: A Guide for Food Services and Restaurants, United 
States Environmental Protection Agency- E.P.A. Last Online retrieved at December, 25 from: (https://www.epa.gov/sites/production/files/2015-09/documents/toolkt_training.pdf).

European Union Committee, (2014). Counting the Cost of Food Waste: EU Food Waste Prevention, the House of Lords, London: The Stationery Office Limited HL Paper 154. Last Online retrieved at December, 25 from: (https://www.parliament.uk/documents/lordscommittees/eu-sub-com-d/food-waste-prevention/154.pdf).

Falasconi, L., Vittuari, M., Politano, A., \& Segrè, A. (2015). Food waste in school catering: An Italian case study. Sustainability, 7(11): 14745-14760.

Ferreira, M., Martins, M.L., \& Rocha, A. (2013). Food waste as an index of foodservice quality, British Food Journal, 115(11), 1628-1637.

Food and Agriculture Organization of the United Nations. (2011). Global Food Losses and Food Waste: Extent, Causes and Prevention. FAO: Rome, Italy.

Food Waste Reduction Alliance. (2014). Best Practices and Emerging Solutions Toolkit. A joint project by the Food Marketing Institute, the Grocery Manufacturers Association \& the National Restaurant Association. SPRING, 1, 1-25.

Food Wise Hong Kong. (2013). Food Waste Reduction: Good Practice Guide for Hotel Sector. Food Wise Hong Kong Campaign May.

Freedman, M. R., \& Brochado, C. (2010). Reducing Portion Size Reduces Food Intake and Plate Waste, Obesity (Silver Spring, Md.),18(9), 1864- 1866.

Göbel, C., Langen, N., Blumenthal, A., Teitscheid, P., \& Ritter, G. (2015). Cutting food waste through cooperation along the food supply chain. Sustainability, 7(2), 1429-1445.

Gunders, D. (2012). Wasted: How America Is Losing Up to $40 \%$ of Its Food from Farm to Fork to Landfill. Natural Resources Defense Council. Last Online retrieved at December, 25 from: (http://www.nrdc.org/food/files/wasted-food-IP.pdf).

Hollins, O. (2013). "Overview of Waste in the UK Hospitality and Food Sector". WRAP's November. Last Online retrieved at December, 25 from: (http://ec.europa.eu/environment/waste/prevention/pdf/SR1008_FinalReport.pdf).

Ishdorj, A., Capps, O., Storey, M., \& Murano, P. S. (2015). Investigating the Relationship between Food Pairings and Plate Waste from Elementary School Lunches. Food and Nutrition Sciences, 6(11), 1029-1044.

Islam, M. (2016). Food Waste in the Hotel Restaurant: A Probable Solution Using Islamic Promotion. Proceedings of Dhaka International Business and Social Science Research Conference, Westin Hotel and Uttara University, Dhaka, Bangladesh, 20-22 January, 141153.

Kallbekken, S., \& Saelen, H. (2013). Nudging' hotel guests to reduce food waste as a win-win environmental measure. Economics Letters, 119(3), 325-327.

Kim, K., \& Morawski, S. (2012). Quantifying the Impact of Going Trayless in a University Dining Hall. Journal of Hunger and Environmental Nutrition., 7(4), 482-486.

Kinasz, T. R., Reis, R. B., \& Morais, T. B. (2015). Presentation of a Validated Checklist as a Tool for Assessing, Preventing and Managing Food Waste in Foodservices. Food and Nutrition Sciences, 6(11), 985-991.

Kitinoja, L. (2016). Innovative Approaches to Food Loss and Waste Issues. Brookings Institution's ending Rural Hunger Project. Frontier Issues Brief. Last Online retrieved at December, 25 from: (https://www.researchgate.net/publication/303185499_Innovative_Approaches_to_Food_Los s_and_Waste_Issues). 
Kuhn, K. (2011). Hospitality industry recycles 'less than half of its waste. Caterer \& Hotelkeeper, 201(4688): 16-7.

Lipinski, B., Hanson, C., Lomax, J., Kitinoja, L., Waite, R. \& Searchinger, T. (2013). Reducing Food Loss and Waste. Working Paper, Installment 2 of "Creating a Sustainable Food Future", World Resources Institute, Washington, DC, USA, May, 1-40.

Manson, E. (2012), Reduce your waste size. Caterer \& Hotelkeeper, 202(4746): 32-3.

Marthinsen, J., Sundt, P., Kaysen, O., \& Kirkevaag, K. (2012). Prevention of food waste in restaurants, hotels, canteens and catering. Nordic Council of Ministers, Norway.

Mena, C., Adenso-Diaz, B., \& Yurt, O. (2011). The causes of food waste in the supplier-retailer interface: Evidences from the UK and Spain. Resources, Conservation and Recycling, 55(6), 648-658.

Östergen, K., \& Gustavsson, J. (2014). Definitional Framework for Food Waste. Last Online retrieved at December, 25 from: (http://www.eufusions.org/phocadownload/Publications/FUSIONS\%20Definitional\%20Framework\%20for \%20Food\%20Waste\%202014.pdf).

Papargyropoulou, E., Lozano, R., Steinberger, J.K., Wright, N., \& Bin-Ujang, Z. (2014). The food waste hierarchy as a framework for the management of food surplus and food waste. Journal of Cleaner Production, 76(1), 106-115.

Parfitt, J., Barthel, M., \& Macnaughton, S. (2010). Food waste within food supply chains: Quantification and potential for change to 2050. Philosophical Transaction of the Royal Society, 365, 3065-3081.

Pirani, S.I., \& Arafat, H.A. (2015). Reduction of Food Waste Generation in the Hospitality Industry. Journal of Cleaner Production, 132(20): 129-145.

Restaurant and Food Service Inspection in Canada. (2014) Canadian food inspection agency, 25 February. Last Online retrieved at December, 25 from: (www.inspection.gc.ca/food/information-for-consumers/report-a-concern/restaurants-andfood-services/eng/1323139279504/1323140830752).

Schneider, F. (2013) Review of Food Waste Prevention on an International Level. Proceedings of the Institution of Civil Engineers, Waste and Resource Management. 166(4): 187-203.

UNEP. (2014). Prevention and reduction of food and drink waste in businesses and households Guidance for governments, local authorities, businesses and other organizations, Version 1.0. Last Online retrieved at December, 25 from: (http://www.fao.org/fileadmin/user_upload/save-food/PDF/Guidance-content.pdf).

Wansink, B., \& van Ittersum, K. (2013). Portion size me: Plate-size induced consumption norms and win-win solutions for reducing food intake and waste. Journal of Experimental Psychology Applied, 19(4), 320-332.

Williams, P., \&Walton, K. (2011). Plate waste in hospitals and strategies for change. Journal of Clinical Nutrition and Metabolism, 6(6), 235-241.

WRAP. (2014). Know How Guide to Reducing and Managing Food Waste in Hotels". International Tourism Partnership, Green Hotelier, September. Last Online retrieved at December, 25 from: (http://www.greenhotelier.org/wp-content/uploads/2014/09/Know-HowGuide-on-Managing-and-Reducing-Food-Waste.pdf).

Wright, S., \& Antonelli, S. (2015). Rebalancing the Food Waste Equation: A Case Study for Santa Barbara, Community Environmental Council, October. 